\title{
第5回アジア学術会議について
}

(平成10年3月11日～13日、於：日本学術会議講堂) 総理府日本学術会議事務局

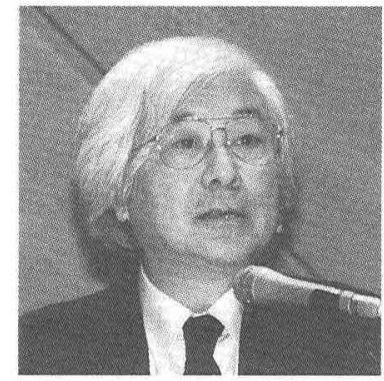

会長 吉川弘之氏

\section{I .アジア学術会議の概要}

\section{1.経緯}

・日本学術会議がアジア9カ国（中国、インド、インド ネシア、韓国、マレーシア、フィリピン、タイ、シ ンガポール、ヴェトナム) からアカデミーの会長等 2 名ずつ計18名を招待し、平成5年度から毎年度開催 している。

\section{2.意義}

(1) 国際学術界におけるアジアの意見の集約・アピール

- 近年、地球的規模の諸問題 (環境、人口、食糧、工 ネルギー問題等) の解決のために、学術界が積極的 に発言しようとする動きが内外で強まっている。

・アジア学術会議では、第1回会議以来、持続的発展が 可能な社会へ移行するためにアジアの学術界が果た すべき役割について討議を重ね、国際学術界におけ るアジアの意見の集約・アピールに貢献してきた。

・ 一方、国際学術界では、インターアカデミーパネル ( I A P ：全世界の80のアカデミ一等が参加、全米 科学アカデミーが事務局）が、持続的発展が可能な 社会へ移行するための課題について討議し、国際社 会に向けてアピールするために、I A P 2000年会議 を2000年5月に開催する予定である。

(2) アジアの技術競争力の底上げと経済ファンダメンタ ルズの強化

・アジア学術会議では、アジア地域に扔いて持続的発 展を可能にするためには、北米、E U 等先進国の技

術の模倣ではない白主技術を開発することにより、 経済ファンダメンタルズを強化することが必要不可 欠であるという議論を重ねてきた。

・最近のアジア各国の厳しい経済情勢の中で、このよ うなアジア学術会議の積み重ねは、アジア各国にお ける科学技術の振興にますます大きな刺激を与えて いる。

\section{II . 第5回アジア学術会議での討議 内容等 \\ 1.内閣総理大臣表敬}

・会議初日（3月11日）午前に行われた総理表敬におい ては、参加者を代表してマレイシア科学アカデミー 会長のラーマン博士からあいさつがあった後、総理 から歓迎のあいさつがあり、20分余にわたって親し く烈談が行われた。

・特に、ラーマン博士からは、「持続可能な発展」とい う会議テーマがアジアにとって時宜を得たものであ ること、日本の科学技術から学ぶものが多いことが 述べられ、橋本総理からは、日本の1970年代の公害 とその克服の過程には自然・人文の双方にまたがる 学術の取組みが必要であったこと、この日本の経験 をアジアの国々のために役立てるためアカデミーの 交流が大切であることが述べられた。

\section{2.基調講演及び学術シンポジウム}

・基調講演 (3月11日) 及び学術シンポジウム (3月12日) 


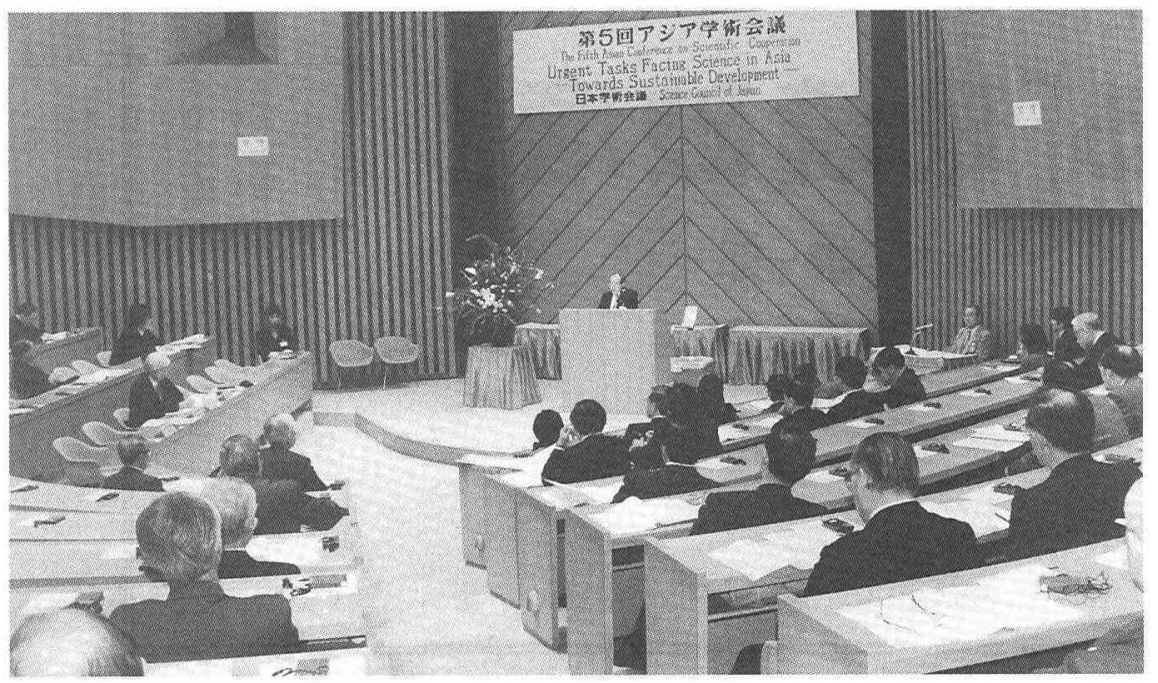

第5回アジア学術会議 基調講演

では、多くの聴衆の集まる中、地球環境問題をはじ めとする地球的規模の諸問題の解決と経済成長との 両立を図り、持続可能な発展を目指すためには学術 が何をなすべきかについて、活発な議論が行われた。

・特に、持続可能な発展のためには、自然・人文双方の 学術分野の協力と再編、政府・企業・アカデミ一間、 さらには各国間の協力が必要であること、政策への 反映のため、科学技術アドバイザリーシステムの改 善、持続可能な科学技術の発展と伝達のための技術 マネージメント手法の採用等が強調された。

・学術シンポジゥム冒頭には、橋本総理のあいさつが、 古川内閣官房副長官によって代読された。

\section{3.セッション}

・セッションでは、アジア学術会議の今後の活動につ いて論議が行われ、IAP2000年会議など地球規模問 題について学術界が積極的に発言しようとする動き が国際的に強まる中で、アジアの意見の集約・アピ 一ルを強化するため、SCA(Science Council of Asia) への移行についても検討がなされるべきであるとさ れた。

・この件について、さらに議論を深めるため、日本学 術会議から、アジア学術会議参加各国（9力国）に、 今秋会員を派遗することになった。

98.3.17 暫定版

\section{第5回アジア学術会議〜科学者フォーラム〜}

(1998年3月11日～13日、於：日本学術会議）

議長サマリーのポイント

1. アジア10カ国（中国、インド、インドネシア、韓国、マレイシア、フィリピン、シンガポール、タイ、ヴェトナム、日本）から 科学者が集まり、「アジアにおける学術の直面する課題〜持続可能な発展に向けて〜」をテーマに、第5回アジア学術会議が、 3月11日〜13日に日本学術会議において開催された。

2. 基調講演及び学術シンポジウムでは、地球環境問題をはじめとする地球的規模の諸問題の解決と経済成長との両立を図り、持続 可能な発展を目指すためには学術が何をなすべきかについて、活発な議論が行われた。

3. セッションでは、アジア学術会議の今後の活動について議論が行われ、日本学術会議から各アジア学術会議参加国 (9力国) に会

員を派遣し、現在のアジア学術会議の発展形であるSCA（Science Council of Asia）について議論を深めることとなった。

4. 少なくとも2000年までは、現行のアジア学術会議が日本学術会議により開催されることが確認された。また、次回（第6回）の アジア学術会議は、1999年に東京で日本学術会議により日本学術会議創立50周年記念事業として開催され、「人口と環境〜持 続可能な発展におけるアジアの危機的な役割」をテーマとすることが合意された。 